\title{
Massive decline of Cystoseira abies-marina forests in Gran Canaria Island (Canary Islands, eastern Atlantic)
}

\author{
José Valdazo, M. Ascensión Viera-Rodríguez, Fernando Espino, Ricardo Haroun, \\ Fernando Tuya \\ Grupo en Biodiversidad y Conservación, IU-ECOAQUA, Universidad de Las Palmas de Gran Canaria, 35017, \\ Las Palmas de G.C., Canary Islands, Spain. \\ (JV) (Corresponding author) E-mail: joanvahe79@gmail.com. ORCID-iD: http://orcid.org/0000-0003-2062-4999 \\ (MAV-R) E-mail: mviera@dbio.ulpgc.es. ORCID-iD: http://orcid.org/0000-0002-6423-619X \\ (FE) E-mail: fesprod@ gobiernodecanarias.org. ORCID-iD: http://orcid.org/0000-0003-3988-7297 \\ (RH) E-mail: ricardo.haroun@ulpgc.es. ORCID-iD: http://orcid.org/0000-0003-1348-692X \\ (FT) E-mail: ftuya@yahoo.es. ORCID-iD: http://orcid.org/0000-0001-8316-5887
}

\begin{abstract}
Summary: Brown macroalgae within the genus Cystoseira are some of the most relevant "ecosystem-engineers" found throughout the Mediterranean and the adjacent Atlantic coasts. Cystoseira-dominated assemblages are sensitive to anthropogenic pressures, and historical declines have been reported from some regions. In particular, Cystoseira abies-marina, thriving on shallow rocky shores, is a key species for the ecosystems of the Canary Islands. In this work, we analyse changes in the distribution and extension of $C$. abies-marina in the last decades on the island of Gran Canaria. This alga dominated the shallow rocky shores of the entire island in the 1980s; a continuous belt extended along $120.5 \mathrm{~km}$ of the coastline and occupied $928 \mathrm{ha}$. In the first decade of the 21 st century, fragmented populations were found along $52.2 \mathrm{~km}$ of the coastline and occupied 12.6 ha. Today, this species is found along $37.8 \mathrm{~km}$ of the coastline and occupies only 7.4 ha, mainly as scattered patches. This regression has been drastic around the whole island, even in areas with low anthropogenic pressure; the magnitude of the decline over time and the intensity of local human impacts have not shown a significant correlation. This study highlights a real need to implement conservation and restoration policies for C. abies-marina in this region.
\end{abstract}

Keywords: marine forests; habitat-forming species; human pressures; Fucales; regression; Atlantic Ocean.

Regresión aguda de los bosques de Cystoseira abies-marina en la isla de Gran Canaria (Islas Canarias, Atlántico este)

Resumen: Las algas pardas pertenecientes al género Cystoseira se distribuyen a lo largo del Mediterráneo y las costas atlánticas adyacentes, siendo uno de los "ingenieros ecosistémicos" más relevantes. Los bosques constituidos por especies de Cystoseira son sensibles a perturbaciones de origen antropogénico y, por esta razón, se han registrado declives históricos en distintas regiones. Concretamente, Cystoseira abies-marina, una especie que habita en costas rocosas someras, es clave para la buena salud de los ecosistemas costeros de las Islas Canarias. En este trabajo, analizamos los cambios en la distribución y extensión de C. abies-marina en las últimas 4 décadas en la isla de Gran Canaria. Esta especie dominaba las costas rocosas poco profundas de toda la isla en la década de los 80; una banda continua se extendía a lo largo de $120.5 \mathrm{~km}$ de costa, ocupando 928 ha. A comienzos del siglo XXI, poblaciones fragmentadas cubrían 12.6 ha, a lo largo de $52.2 \mathrm{~km}$ de la línea de costa. Hoy en día, se distribuye a lo largo de $37.8 \mathrm{~km}$ del perímetro costero, en su mayoría como parches dispersos, ocupando una extensión de tan sólo 7.4 ha. Esta regresión ha sido drástica en toda la isla, incluso en zonas con baja presión antropogénica; no encontramos una correlación significativa entre el número de impactos locales y la magnitud del declive en el tiempo. Este estudio señala la necesidad real de implementar políticas de conservación y restauración para C. abies-marina en esta región.

Palabras clave: bosques marinos; especies formadoras de hábitats; presiones humanas; Fucales; regresión; Océano Atlántico.

Citation/Como citar este artículo: Valdazo J., Rodríguez-Rodríguez M.A., Espino F., Haroun R., Tuya F. 2017. Massive decline of Cystoseira abies-marina forests in Gran Canaria Island (Canary Islands, eastern Atlantic). Sci. Mar. 81(4): 499507. doi: http://dx.doi.org/10.3989/scimar.04655.23A

Editor: E. Ballesteros.

Received: April 18, 2017. Accepted: September 05, 2017. Published: November 2, 2017.

Copyright: (c) 2017 CSIC. This is an open-access article distributed under the terms of the Creative Commons Attribution (CC-by) Spain 3.0 License. 


\section{INTRODUCTION}

Coastal ecosystems are suffering severe impacts worldwide due to excessive human pressure. Habitat destruction, pollution, eutrophication, species introduction, overfishing and global warming, which often act synergistically, are affecting species, ecosystems and their ability to provide ecosystem services (Halpern et al. 2008). For example, the Canary Islands are a "hot spot" of marine biodiversity in the North Atlantic (Sansón et al. 2001), which is threatened by human impacts, e.g. pollution, overfishing, occupation of the coast and progressive tropicalization (Riera et al. 2015).

Along rocky shores of temperate and subtropical areas, large canopy-forming brown algae, in particular kelps (Laminariales, Phaeophyceae, Ochrophyta) and fucoids (Fucales, Phaeophyceae, Ochrophyta), are the dominant species in pristine environments (Schiel and Foster 2006). These large perennial macroalgae are considered as "engineering species" (Jones et al. 1994), because their three-dimensional structure dramatically alters the physical, chemical and biological environment. These forests provide shelter, food, habitat and nurseries for a multiplicity of species (Cheminée et al. 2013). The decline of kelps and fucoids is a global phenomenon due, directly or indirectly, to humanmediated activities (Wernberg et al. 2011, LamelaSilvarrey et al. 2012, Franco et al. 2015). Some species have even been driven to regional and local extinction (Thibaut et al. 2005, Franco et al. 2015, Thibaut et al. 2016a). The loss of these well-structured and diverse ecosystems facilitates the appearance of less complex habitats, such as filamentous algal turfs, ephemeral seaweed assemblages and barren grounds dominated by encrusting algae and sea urchins (Benedetti-Cecchi et al. 2001, Ling et al. 2015).

The genus Cystoseira C. Agardh (Fucales, Phaeophyta) is distributed in temperate and subtropical coasts around the world, although $80 \%$ of the species live in the Mediterranean Sea (Oliveras and Gómez 1989). In the Mediterranean and the adjacent Atlantic Ocean, species of the genus Cystoseira are the main group of habitat-forming macroalgae, from the littoral to the lower limit of the euphotic zone (Giaccone et al. 1994, García-Fernández and Bárbara 2016). Losses of Cystoseira forests have been reported all around the Mediterranean and attributed to habitat destruction, eutrophication and overgrazing by herbivores (Thibaut et al. 2005, Iveša et al. 2016, Blanfuné et al. 2016a). Due to their high sensitivity to anthropogenic impacts, several species of Cystoseira indicate high quality waters and facilitate the implementation of the EU Water Framework Directive (2000/06/EC) (Ballesteros et al. 2007, Blanfuné et al. 2016b, 2017). All the Mediterranean species of the genus Cystoseira, except $C$. compressa, have been protected under the Annex II of the Barcelona Convention (2010). Five species, Cystoseira amentacea, Cystoseira mediterranea, Cystoseira sedoides, Cystoseira spinosa and Cystoseira zosteroids, are protected under the Berne Convention (Annex I, 1979). In addition, all Mediterranean Cystoseira species are under surveillance by international organiza- tions, such as IUCN, RAP/ASP and MedPan (Thibaut et al. 2014). All species of Cystoseira are "habitatforming" and are therefore considered EU habitats of interest (Micheli et al. 2013).

The brown alga Cystoseira abies-marina (S. G. Gemelin) C. Agardh has been considered the most abundant fucoid species on rocky shores of the Canarian Archipelago (Wildpret et al. 1987, Tuya and Haroun 2006), and its populations typically form extensive stands in both the eulittoral and shallow sublittoral, mainly on rocky wave-exposed zones (Wildpret et al. 1987, Medina and Haroun 1993). C. abies-marina is a caespitose plant with large numbers of erect branches, up to $50 \mathrm{~cm}$ long. Similar to other species in the genera Cystoseira, this species undergoes an annual thallus loss at the end of summer, when a high proportion of the fronds break down at the base. The holdfasts overwinter and regrow the next year. Therefore, although individuals are perennial, the thalli are annual (Buonomo et al. 2017). However, the plant never goes through a total rest phase: during unfavourable months, branches from different seasons coexist (González-Rodríguez and Afonso-Carrillo 1990). This alga spreads through both vegetative propagation and sexual reproduction (Medina 1997). Similar to other species of the genus, thalli are negatively buoyant and propagules normally settle at $<20-40 \mathrm{~cm}$ from the source population (Mangialajo et al. 2012), which gives the species a lowdispersal ability (Bulleri et al. 2002). This is one of the most productive macroalgae in the Canary Islands (Johnston 1969), and at the end of summer, after the maximum reproductive peak, it is possible to find a large amount of wrack on beaches from nearby forests (Portillo-Hahnefeld 2008).

In the last few decades, Cystoseira abies-marina forests have declined significantly at certain points of the Canaries (Medina and Haroun 1993, Rodríguez et al. 2008). In order to analyse the long-term patterns in the distribution and extension of C. abies-marina along the entire coastal perimeter of the island of Gran Canaria, we collected all available data to reconstruct historical distributions. The aims were: (i) to provide an up-to-date assessment of the current distribution and extent of $C$. abies-marina, (ii) to facilitate a comparison with historical data, including populations from certain sites, and (iii) to evaluate the influence of local anthropogenic pressures, as drivers of regression.

\section{MATERIALS AND METHODS}

\section{Study area}

The island of Gran Canaria $\left(28^{\circ} 51^{\prime} \mathrm{N}, 15^{\circ} 36^{\prime} \mathrm{W}\right)$ is located $200 \mathrm{~km}$ off the northwest African coast, in the middle of the Canary Islands (east Atlantic) (Fig. 1). The island has a circular shape of $256 \mathrm{~km}$ of coastal perimeter. Abrupt cliffs mostly dominate the north and west sides of the island, with coastal platforms and beaches predominating in the east and south. Although $76.02 \%$ of the coastal perimeter is rocky (Ramírez et al. 2008), rocky reefs only account for $17 \%$ of the shallow-water bottoms (up to $50 \mathrm{~m}$ ). Gran Canaria is 


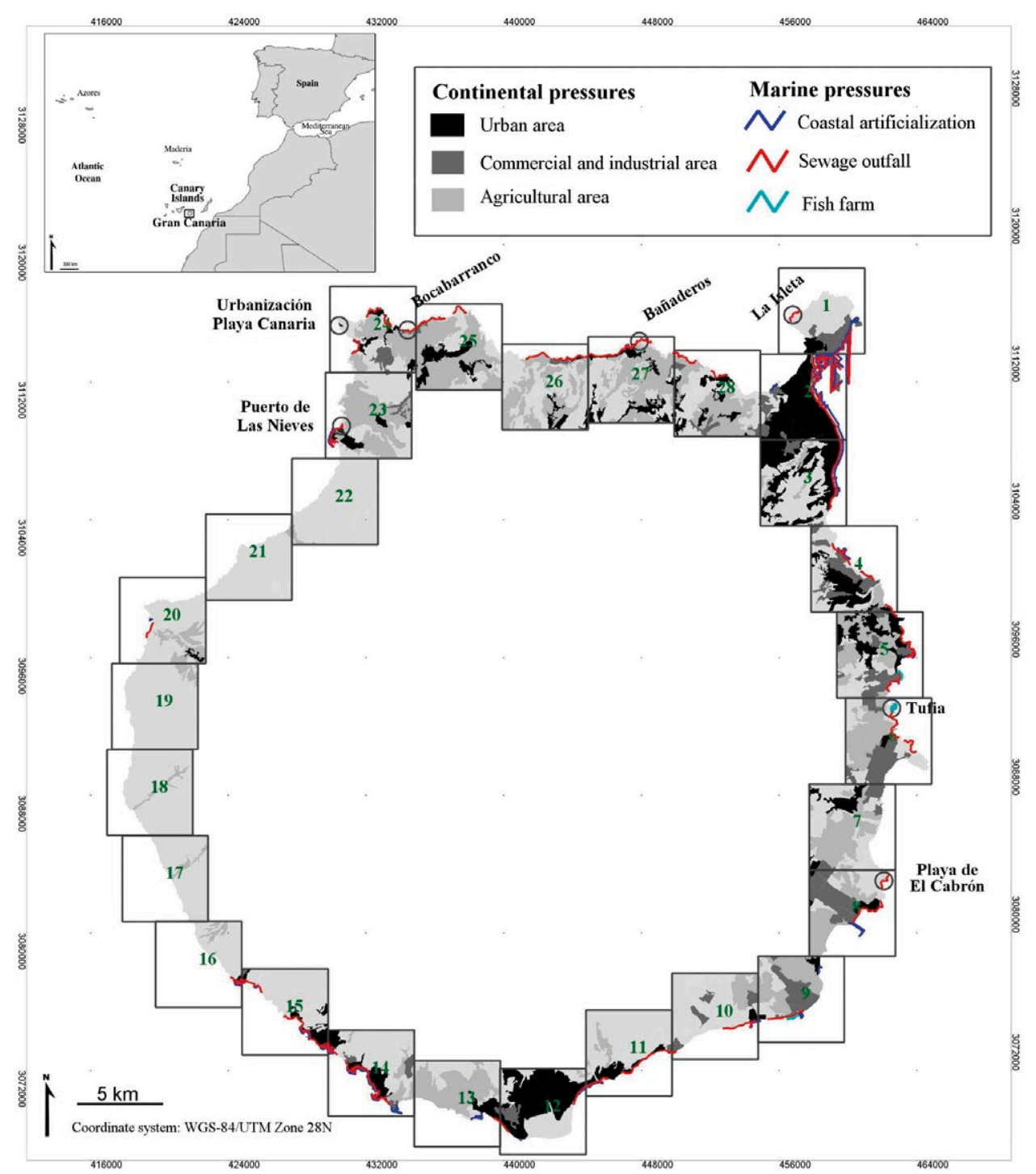

Fig. 1. - Map of Gran Canaria Island, including the 28 sectors (grids of $5 \times 5 \mathrm{~km}$ ) encompassing the entire coastal perimeter. The location of the seven analysed populations is also shown, with the circular area (500 m radius) where the HAPI index was calculated.

situated at the centre of a west-east oceanographic gradient along the Canarian archipelago, because of the varying proximity from the upwelling of the African coast (Tuya et al. 2006). The waters are typically oligotrophic and the surface temperature varies between $18^{\circ} \mathrm{C}$ in March and $24^{\circ} \mathrm{C}$ in October.

\section{Mapping historical and current distribution: GIS analysis}

Changes in the distribution ( $\mathrm{km}$ of coastal perimeter) and extent (occupied area in ha) of Cystoseira abiesmarina over time were analysed with the open-source GIS (gvSIG) and Sextante tools, using a 1:2500 scale and a WGS-84/UTM Zone 28N coordinate system.

Historical records concerning Cystoseira abiesmarina distribution in the Canary Islands are scarce (Table 1). To reconstruct long-term patterns of change, we used unpublished reports from the late 1980s and 2000s, and oral scientific contributions. However, we did not take into account herbarium vouchers. The first map dates back to 1985, when Wildpret et al. (1987) defined and mapped 15 types of vegetation between 0 and $10 \mathrm{~m}$ depth: 12 correspond to stands of macroalgae, two to seagrass meadows and one to a mixed community of seagrass and algae. Additionally, they mapped three ecosystems devoid of vegetation. We digitalized six of these types of vegetation, in which C. abies-mari$n a$ was the principal floral component (Supplementary material Table S1, Fig. S1A). We used complementary sources to enlarge this map from the 1980s, focusing mainly on the eastern side of the island. Information provided by scientists and technicians, which was contrasted with historical orthophotos (Vuelos históricos: 1989-1991 Costas, Instituto Geográfico Nacional),

Table 1. - Cartographic sources on the distribution of Cystoseira abies-marina in Gran Canaria Island.

\begin{tabular}{lll}
\hline $1980 \mathrm{~s}$ & 1987 & Wildpret et al. (1987) \\
$2000 \mathrm{~s}$ & 1989 & Oral scientific communications \\
$2010 \mathrm{~s}$ & 2008 & Rodríguez et al. (2008) \\
\hline
\end{tabular}


supplied additional populations to those provided by Wildpret et al. (1987) (Supplementary material Table S1, Fig. S1B).

The first digitalized map of Cystoseira abies-mari$n a$ was undertaken in 2008 by Rodríguez et al. (2008), who mapped the distribution of $C$. abies-marina according to three levels of abundance: as continuous belts, as discontinuous belts and as isolated individuals (Fig 2B).

Field surveys were carried out between 2015 and 2016, during the maximum development of Cystoseira abies-marina (spring to autumn). The entire coast of Gran Canaria was explored on foot or by boat, and the shallow subtidal by snorkelling. Locally, populations were categorized, following Rodríguez et al. (2008), as $\mathrm{C} 1$, rare scattered patches; $\mathrm{C} 2$, abundant patches; and $\mathrm{C} 3$, continuous belts. All the C. abies-marina populations were geo-localized and recorded on A4 format aerial photographs from the IGN (Instituto Geográfico Nacional, 1:2500 scale).

\section{Comparison of populations: 2008 vs 2016}

Rodríguez et al. (2008) studied seven populations (Fig. 1), providing the average coverage and belt width of Cystoseira abies-marina forests. In 2016, we repeated the study in the same locations, carrying out three transects (ca. $10 \mathrm{~m}$ apart), which covered the entire eulittoral and the shallow subtidal. Along each transect, the coverage $(\mathrm{n}=3)$ of $C$. abies-marina was obtained with a square $(50 \times 50 \mathrm{~cm})$, divided into 25 sub-squares of $10 \times 10 \mathrm{~cm}$; the belt width was measured with a transect. We tested for differences in average coverage and belt width between 2008 and 2016 using a Wilcoxon test (i.e. all populations were pooled).

\section{Human pressures as drivers of change}

We assessed the Human Activities and Pressures Index (HAPI) (Blanfuné et al. 2017) on the coast of Gran Canaria. Five water bodies (WD) surround the island, according to the Water Framework Directive (WFD, 2000/60/EC). We divided these WD into 28 coastal sectors (grid cells of $5 \times 5 \mathrm{~km}$, Fig. 1) to identify more precisely the relationship between levels of anthropogenic pressures and the decline of Cystoseira abies-marina forests. For this study, we adapted the information available for the Canary Islands, following the method of Blanfuné et al. (2017).

The HAPI index has three metrics to estimate both continental and marine pressures. For continental pressures (urban, industrial and agricultural areas), the three metrics were expressed as the percentage of land area covered (data from Corine Land Cover 2012, available at centrodedescargas.cnig.es) within each coastal sector. For marine pressures, we estimated (i) the level of artificialization of the coast, expressed as the percentage of the artificialized coastline, (ii) fish farms, expressed as the percentage of rocky coastline potentially impacted (within a $500 \mathrm{~m}$ radius), and (iii) sewage outfalls, expressed as the percentage of rocky coastline potentially impacted (within a $500 \mathrm{~m}$
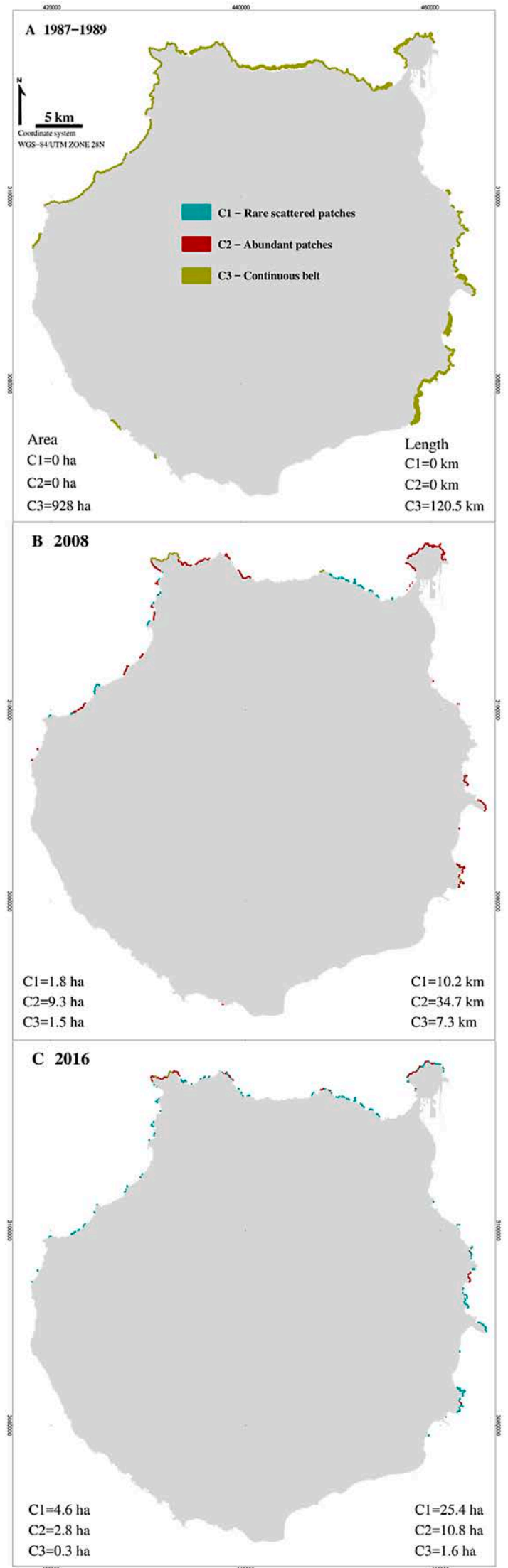

Fig. 2. - Distribution of Cystoseira abies-marina around Gran Canaria Island in the 1980s (A), 2008 (B) and 2016 (C). The area (ha) and length $(\mathrm{km})$ of the three types of stands is included $(\mathrm{C} 1$, scattered patches; $\mathrm{C} 2$, abundant patches; $\mathrm{C} 3$, continuous belt). 
radius). This information was provided by the on-line GIS of the Canary Islands Autonomous Government (www.idecanarias.es). For each sector, we calculated the change in the extent of $C$. abies-marina between 1980s (i.e. Wildpret et al. 1987) and 2016 (i.e. this study). We applied a linear regression to test whether varying levels of human pressures explained the magnitude of changes in surface area over time at the island scale. Additionally, the HAPI index was calculated for each of the seven populations under study; we calculated the level of human pressures using a $500 \mathrm{~m}$ radius circular buffer from the centre of each population (Fig. 1), following a similar approach to that of Tuya et al. (2014).

\section{RESULTS}

\section{Distribution and extent}

During the 1980s (Fig. 2A), Cystoseira abies-mari$n a$ dominated the rocky coasts of Gran Canaria, along $120.5 \mathrm{~km}$ of coastal perimeter, covering 928 ha. It was abundant on most rocky substrates and the populations were mainly composed of continuous belts (Fig. 2A). Subtidal populations reached up to $9 \mathrm{~m}$ depth in many places of the north coast; in the east and southeast coast, stands reached up to $20 \mathrm{~m}$ depth in some places. The species was absent from the south and southwestern coast, mainly due to a lack of suitable hard substrates. At the start of the 21st century (Fig. 2B), populations were clearly fragmented, occupying $52.2 \mathrm{~km}$ of the coast (19.45\% of the coastline) and covering 12.6 ha; this corresponds to a regression of $98.64 \%$ in 20 years. Populations rarely get down into the subtidal, except in a few locations in the north and east, where populations go down to 8-10 m. Between 2014 and 2016, C. abies-marina was present along $37.8 \mathrm{~km}(14.08 \%$ of the coastline) and occupied an area of only 7.4 ha. Populations forming continuous belts have practically disappeared (0.3 ha). Fragmented populations are becoming more prominent and sublittoral populations have totally disappeared. As a result, $\mathrm{ca}$. $99 \%$ of the area formerly covered by $C$. abies-marina has been lost in a few decades (Fig. 3).

\section{Comparison of populations: 2008 vs 2016}

Overall, the seven Cystoseira abies-marina populations studied in 2016 have suffered a significant decline relative to 2008, in terms of coverage $(\mathrm{V}=231, \mathrm{P}=0.00006$, Fig. 4A) and belt width $(\mathrm{V}=231$, $\mathrm{P}=0.0000001$, Fig. 4B). In 2008, all populations had high cover $(>50 \%)$ and formed continuous belts; in some localities, belts extended to the subtidal down to 8-10 m depth.

\section{Human pressures as drivers of regression}

Values of the HAPI index were calculated for the 28 coastal sectors and 7 populations of Gran Canaria Island (Tables 2 and 3, Supplementary material Table S3). There was no significant effect of varying
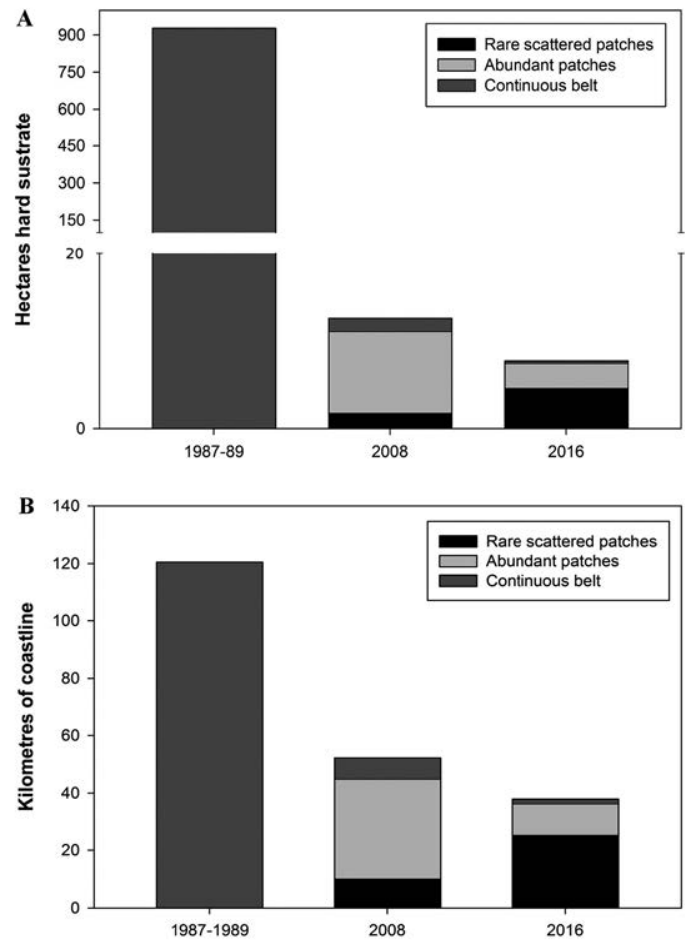

Fig. 3. - Temporal changes in the extent of Cystoseira abies-marina, in terms of the surface in hectares (A) and length in kilometres (B) of the coastline occupied at different times.
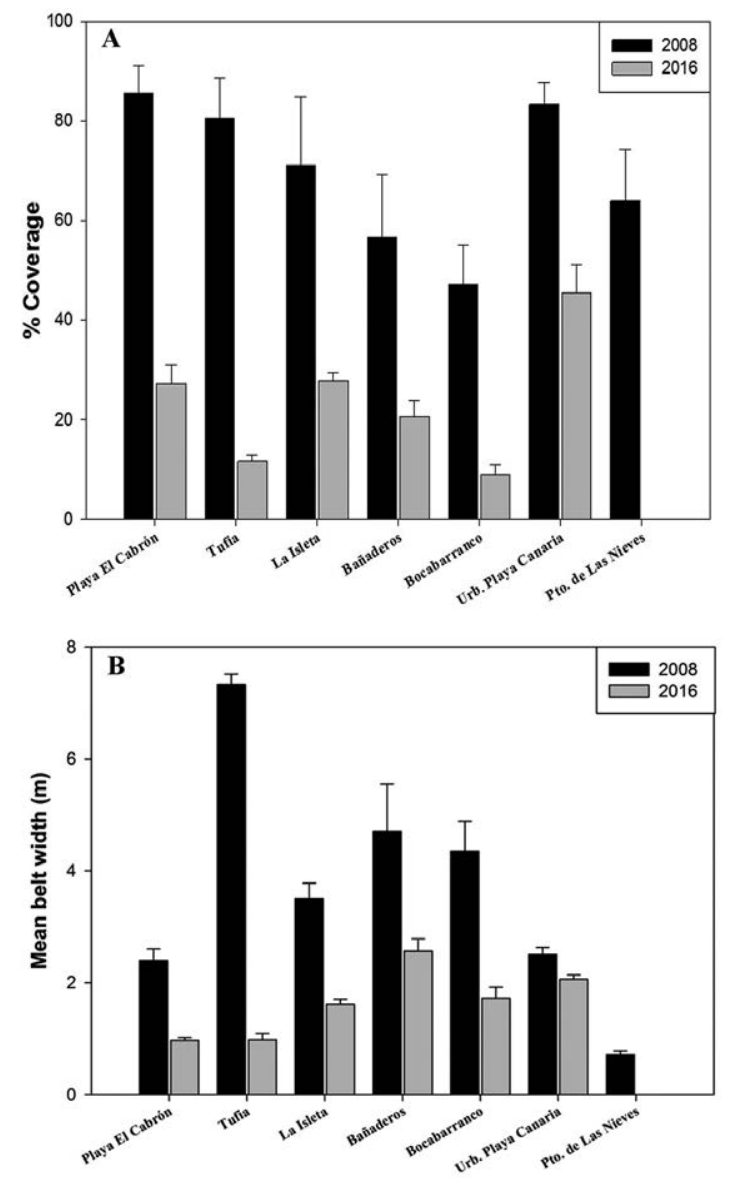

Fig. 4. - Average coverage in percentage (A) and belt width in metres (B) of the seven populations of Cystoseira abies-marina in 2008 and 2016. 
Table 2. - Values of the HAPI index, area covered and rate of temporal change of Cystoseira abies-marina in each of the 28 sectors along the coastal perimeter of Gran Canaria.

\begin{tabular}{|c|c|c|c|c|}
\hline \multirow[b]{2}{*}{ Sector } & \multirow[b]{2}{*}{ HAPI index } & \multicolumn{2}{|c|}{ Area (ha) } & \multirow[b]{2}{*}{$\%$ Change } \\
\hline & & $1980 \mathrm{~s}$ & 2016 & \\
\hline 1 & 3.24 & 83.86 & 0.81 & -99.03 \\
\hline 2 & 5.48 & 31.72 & 0 & -100 \\
\hline 3 & 4.09 & 0 & 0 & 0 \\
\hline 4 & 3.58 & 6.73 & 0.06 & -99.11 \\
\hline 5 & 4 & 30.51 & 1.75 & -94.26 \\
\hline 6 & 2.81 & 62.65 & 0.55 & -99.12 \\
\hline 7 & 0.83 & 77.07 & 0.075 & -99.9 \\
\hline 8 & 4.55 & 131.23 & 0.46 & -99.65 \\
\hline 9 & 4.85 & 118.9 & 0 & -100 \\
\hline 10 & 3.13 & 0 & 0 & 0 \\
\hline 11 & 4.09 & 0 & 0 & 0 \\
\hline 12 & 4.19 & 0 & 0 & 0 \\
\hline 13 & 3.84 & 0 & 0 & 0 \\
\hline 14 & 4.09 & 6.6 & 0 & -100 \\
\hline 15 & 4.44 & 5.66 & 0 & -100 \\
\hline 16 & 4.37 & 0 & 0 & 0 \\
\hline 17 & 0.07 & 0 & 0 & 0 \\
\hline 18 & 0.06 & 0 & 0 & 0 \\
\hline 19 & 0.06 & 8.61 & 0.05 & -99.42 \\
\hline 20 & 1.8 & 12.39 & 0.12 & -99.03 \\
\hline 21 & 0.04 & 29.95 & 0.09 & -99.7 \\
\hline 22 & 0.04 & 16.53 & 0.07 & -99.58 \\
\hline 23 & 2.44 & 13.5 & 0.14 & -98.97 \\
\hline 24 & 1.93 & 42.85 & 1.5 & -96.5 \\
\hline 25 & 1.53 & 50.64 & 0.53 & -98.96 \\
\hline 26 & 1.42 & 95.03 & 0.06 & -99.99 \\
\hline 27 & 2.55 & 58.68 & 0.47 & -99.2 \\
\hline 28 & 1.52 & 45.04 & 1.01 & -98.99 \\
\hline
\end{tabular}

Table 3. - Values of the HAPI index, coverage and rate of temporal change for each of the seven studied Cystoseira abies-marina populations.

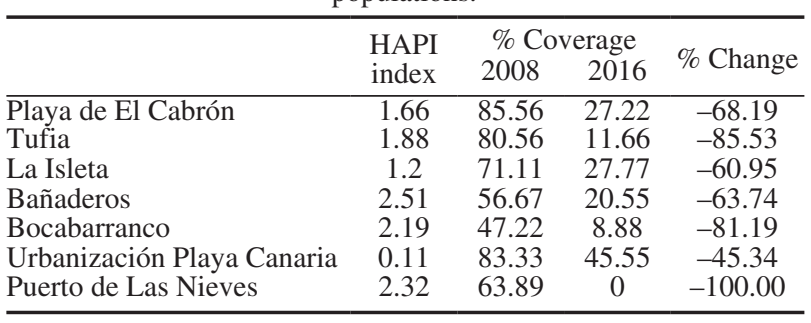

levels of human pressures on temporal changes for either extent (1980s vs 2016; $\mathrm{R}^{2}=0.048, \mathrm{~F}=0.0423$, $\mathrm{df}=18, \mathrm{P}=0.839$ ) or coverage of $C$. abies-marina ( 2008 vs $2016 ; \mathrm{R}^{2}=0.53, \mathrm{~F}=5.77, \mathrm{df}=5, \mathrm{P}=0.06$ ). In general, the magnitude of regression, in terms of both extent and coverage, has been high in all sectors and for all populations, even in areas with low or no human pressure.

\section{DISCUSSION}

Changes in the distribution and extent of Cystoseira abies-marina on the island of Gran Canaria over the last few decades are evident and dramatic. In the late 1980s, C. abies-marina occupied 928 ha $(12.84 \%$ of the rocky bottoms) and now it only covers 7.4 ha $(0.1 \%)$. Existing C. abies-marina populations have been reduced to narrow belts in the lower eulittoral, i.e. as scattered patches with underdeveloped branches. Our results are in agreement with those found for other Cystoseira species from the Mediterranean Sea (Thibaut et al. 2005, Mangialajo et al. 2008, Sales et al. 2011), for other fucoids from the Canary Islands (Rod- ríguez et al. 2008, Riera et al. 2015) and, in general, for habitat-forming brown algae worldwide (Wahl et al. 2015). Our data show a similar trend to that observed for C. brachyccarpa var. brachycarpa, a species having the same depth range and ecological function as C. abies-marina, including a massive decline from the sublittoral to a narrow fringe immediately below the surface (Thibaut et al. 2015, 2016b).

It is plausible that the area occupied by Cystoseira abies-marina in the 1980s is not entirely accurate, because of the lack of technical procedures to accurately trace communities at this time. The map of Wildpret et al. (1987) only reached $10 \mathrm{~m}$ depth, so they may even have underestimated the area occupied by $C$. abiesmarina. Even assuming these inaccuracies, the regression of $C$. abies-marina is acute, in particular because all sublittoral populations have been lost.

In our study, we found no direct relationship between local levels of anthropogenic pressures and the magnitude of local regression; the decay has been dramatic from almost pristine environments to highly altered coasts. This result contrasts with the disappearance of some Cystoseira species only from highly artificialized areas (harbours, marinas, piers, etc.) and waters severely polluted in the Mediterranean (Thibaut et al. 2014, 2015, Iveša et al. 2016). However, a similar decline has been observed in the pristine environments of the National Park of Port-Cros in France (Thibaut et al. 2016b). In a similar study, the temporal decay in the vitality of the seagrass Cymodocea nodosa in Gran Canaria was connected with an increase in local anthropogenic impacts (Tuya et al. 2014).

The decline of $C$. abies-marina in Gran Canaria has occurred in a period of pronounced urban and tourism development and, therefore, of many local impacts (Tuya et al. 2014, Ferrer-Valero et al. 2017). Today, the population, urbanization and infrastructure are heavily concentrated on the coast of the island, particularly in the northeast, east and south (Fig. 1). Gran Canaria currently has 847830 inhabitants and a very high population density (543 inhabitants $\mathrm{km}^{-2}$ ) (ISTAC 2015); $87 \%$ of the population is located along the littoral perimeter, giving a coastal population density of 3142 ind $\mathrm{km}^{-1}$. In addition, about 2 million tourists visit the island every year (e.g. 1805058 tourists in 2015, ISTAC 2015). This has led to the occupation and degradation of most coastal areas (Ferrer-Valero et al. 2017). Importantly, however, populations of C. abies-marina in poorly impacted areas have also suffered significant regressions. Hence, it remains elusive to unravel the reasons for the loss of C. abies-marina.

The possible causes of the decline may be multiple and cumulative, as happens around the world (Thibaut et al. 2005, Wahl et al. 2015, Franco et al. 2015). Potentially, both local and global stressors are interacting to explain the severe regression of Cystoseira abies-marina in Gran Canaria, as is the case with the disappearance of other fucoids from the study region (Riera at al. 2015). In the Canary Islands, sea surface temperature has increased about $1{ }^{\circ} \mathrm{C}$ in recent decades (Lima and Wethey 2012, Riera 
et al. 2015). Global warming is a key factor in the ongoing decline of fucoids and their displacement to colder waters (Wernberg et al. 2011). There is recent regional evidence of the adverse effect of warming on species of both brown and red macroalgae (Sansón et al. 2013). The decrease in the size of thalli of these seaweeds, and in their reproductive success (Zhang et al. 2009), have also been correlated with the warming of the Canarian waters (Sansón et al. 2013, Riera et al. 2015). Furthermore, Cystoseira are low-dispersal species whose propagules do not have a planktonic stage, and reproductive drifting thalli in floating rafts are the main mechanism of connectivity between populations (Susini et al. 2007). Therefore, if connectivity is limited, the subsequent smaller population gene pools and sizes render populations more vulnerable to threats (Buonomo et al. 2017).

The regime shift from marine forests to barren grounds devoid of erect macroalgae is generally linked to overexploitation of predatory fishes (Ling et al. 2015, Thibaut et al. 2015, 2016a). In the Canary Islands, the long-spined sea urchin Diadema africana controls the transition from rocky bottoms dominated by erect macroalgae to barren grounds (Tuya et al. 2004, Sangil et al. 2014). This sea urchin may consume thalli of C. abies-marina at rates of 1-2 $\mathrm{mg}$ of algae per day and individual (Tuya et al. 2001). In addition, it is plausible that the sea urchin Paracentrotus lividus and herbivorous fishes (Sparisoma cretense, Sarpa salpa and Diplodus spp.) can contribute to the consumption of $C$. abies-marina, as in the Mediterranean for other Cystoseira spp. (Verges et al. 2009).

This study highlights the urgent need to monitor remaining Cystoseira abies-marina populations of the Canary Islands, and compare this data with other Macaronesian islands. It is also necessary to promote urgent actions to conserve current populations, including restoration programmes. Currently, C. abies-mari$n a$ is regionally protected within the framework of the Canary Islands Catalogue of Protected Species (Law 4/2010, of 4 June 2010). This highlights the uselessness of legislation if it is not enforced. Furthermore, in the last update of this catalogue, the species lost the category of "vulnerable": it now belongs to a recently created category called "species of interest for the Canarian ecosystems", which only protects the species within zones of the Natura 2000 network. Our results clearly do not support this legislative change.

Cystoseira abies-marina has not yet been assessed for the IUCN Red List, i.e. it is "Not Evaluated" (IUCN 2017), nor is species included in the Catalogue of Life (Roskov et al. 2016). We are aware that $C$. abies-mari$n a$ is undergoing a very important decline throughout the Canaries (Rodríguez et al. 2008) and also on Madeira and the Azores (Ballesteros pers. com.), but more data are needed to verify the magnitude of this decline. Nevertheless, with current data and evidence of the regional decline, we propose that $C$. abies-marina should be classified as "Critically Endangered" under the IUCN criteria CR A2ac. There are only very few algal species in the world whose conservation status has been properly assessed (Blanfuné et al. 2016a), due to lack of historical data. Information provided here could be used as a basis for improving the evaluation of the conservation status of $C$. abies-marina, an ecologically important species.

\section{ACKNOWLEDGEMENTS}

This work was partly supported by the University of Las Palmas through a research technician contract to José Valdazo. We thank Alejandro Garcia and Tony Sánchez for their help during different stages of this work. We would like to thank Agustín López Valido for his assistance in translating the paper, and the recommendations from two anonymous reviewers to improve the manuscript.

\section{REFERENCES}

Ballesteros E., Torras X., Pinedo S., et al. 2007. A new methodology based on littoral community cartography for the implementation of the European Water Framework Directive. Mar. Poll. Bull. 55: 172-180. https://doi.org/10.1016/j.marpolbul.2006.08.038

Benedetti-Cecchi L., Pannacciulli F., Bulleri F., et al. 2001. Predicting the consequences of anthropogenic disturbance: large-scale effects of loss of canopy algae on rocky shores. Mar. Ecol. Prog. Ser. 214: 137-150 https://doi.org/10.3354/meps 214137

Blanfuné A., Boudouresque C.F., Verlaque M., et al. 2016a. The fate of Cystoseira crinita, a forest-forming Fucale (Phaeophyceae, Stramenopiles), in France (North Western Mediterranean Sea). Est. Coast. Shelf Sci. 181: 196-208. https://doi.org/10.1016/j.ecss.2016.08.049

Blanfuné A., Boudouresque C.F., Verlaque M., et al. 2016b. Response of rocky shore communities to anthropogenic pressures in Albania (Mediterranean Sea): ecological status assessment through the CARLIT method. Mar. Poll. Bull. 109: 409-418. https://doi.org/10.1016/j.marpolbul.2016.05.041

Blanfuné A., Thibaut T., Boudouresque C.F., et al. 2017. The CARLIT method for the assessment of the ecological quality of European Mediterranean waters: Relevance, robustness and possible improvements. Ecol. Indic. 72: 249-259. https://doi.org/10.1016/j.ecolind.2016.07.049

Bulleri F., Benedetti-Cecchi L., Acunto S., et al. 2002. The influence of canopy algae on vertical patterns of distribution of low shore assemblages on rocky coasts in the northwest Mediterranean. J. Exp. Mar. Biol. Ecol. 267: 89-106. https://doi.org/10.1016/S0022-0981(01)00361-6

Buonomo R., Assis J., Fernandes F., et al. 2017. Habitat continuity and stepping-stone oceanographic distances explain population genetic connectivity of the brown alga Cystoseira amentacea. Mol. Ecol. 26: 766-780. https://doi.org/10.1111/mec.13960

Cheminée A., Sala E., Pastor J., et al. 2013. Nursery value of Cystoseira forests for Mediterranean rocky reef fishes. J. Exp. Mar. Biol. Ecol. 442: 70-79. https://doi.org/10.1016/j.jembe.2013.02.003

Ferrer-Valero N., Hernández-Calvento L., Hernández-Cordero A.I. 2017. Human impacts quantification on the coastal landforms of Gran Canaria Island (Canary Islands). Geormorphology 286: 58-67. https://doi.org/10.1016/j.geomorph.2017.02.028

Franco J.N., Wernberg T., Bertocci I., et al. 2015. Herbivory drives kelp recruits into 'hiding' in a warm ocean climate. Mar. Ecol. Prog. Ser. 536: 1-9. https://doi.org/10.3354/meps 11445

García-Fernández A., Bárbara I. 2016. Studies of Cystoseira assemblages in Northern Atlantic Iberia. An. Jard. Bot. Madrid 73: e035. https://doi.org/10.3989/ajbm.2403

Giaccone G., Alongi G., Pizzuto F., et al. 1994. La Vegetazione marina bentonica fotofila del Mediterraneo: 2: Infralitorale e Circalitorale: proposte di aggiornamento. Boll. Accad. Gioenia Sci. Nat. Catania 27(346): 111-157.

González-Rodríguez R.M., Afonso-Carrillo J. 1990. Estudio fe- 
nológico de cuatro especies de Cystoseira C. Agardh (Phaeophyta, Fucales) en Punta del Hidalgo, Tenerife (Islas Canarias). Vieraea 18: 205-234.

Halpern B.S., Walbridge S., Selkoe K.A., et al. 2008. A global map of human impact on marine ecosystems. Science 319(5865): 948-952.

https://doi.org/10.1126/science.1149345

ISTAC. 2015. Anuario Estadístico de Canarias 2014. Instituto Canario de Estadística, Gobierno de Canarias.

IUCN. 2017. The IUCN Red List of Threatened Species. Version 2017-1. Accessed on 10 July 2017. www iucnredlist.org

Iveša L., Djakovac T., Devescovi M. 2016. Long-term fluctuations in Cystoseira populations along the west Istrian Coast (Croatia) related to eutrophication patterns in the northern Adriatic Sea. Mar. Poll. Bull. 106: 162-173. https://doi.org/10.1016/j.marpolbul.2016.03.010

Johnston C.S. 1969. Studies on the ecology and primary production of Canary Island marine algae. Proc. Int. Seaweed Symp. 6: 213-222.

Jones C.G., Lawton J.H., Shachak M. 1994. Organisms as ecosystem engineers. Oikos 69: 373-386. https://doi.org/10.2307/3545850

Lamela-Silvarrey C., Fernández C., Anadón R., et al. 2012. Fucoid assemblages on the north coast of Spain: past and present (1977-2007). Bot. Mar. 55: 199-207. https://doi.org/10.1515/bot-2011-0081

Lima F.P., Wethey D.S. 2012. Three decades of high-resolution coastal sea surface temperatures reveal more than warming. Nat. Commun. 3: 704. https://doi.org/10.1038/ncomms 1713

Ling S.D., Scheibling R.E., Rassweiler A., et al. 2015. Global regime shift of catastrophic sea urchin overgrazing. Phil. Trans. R. Soc. B 370: 20130269. https://doi.org/10.1098/rstb.2013.0269

Mangialajo L., Chiantore M., Cattaneo-Vietti R. 2008. Loss of fucoid algae along a gradient of urbanisation and relationships with the structure of benthic assemblages. Mar. Ecol. Prog. Ser. 358: 63-74. https://doi.org/10.3354/meps07400

Mangialajo L., Chiantore M., Susini M.L., et al. 2012. Zonation patterns and interspecific relationships of fucoids in microtidal environments. J. Exp. Mar. Biol. Ecol. 412: 72-80. https://doi.org/10.1016/j.jembe.2011.10.031

Medina M. 1997. Estudio ecofisiológico de las praderas de Cystoseira abies-marina (S.G. Gmel.) C. Agardh en el Archipiélago Canario. PhD thesis, Tech. Univ. La Laguna, 155 pp.

Medina M., Haroun R. 1993. Preliminary study on the dynamics of Cystoseira abies-marina population in Tenerife (Canary Island). Cour. Forschinst. Senckenb. 159: 109-112.

Micheli F., Levin N., Giakoumi S., et al. 2013. Setting priorities for regional conservation planning in the Mediterranean Sea. PLoS ONE 8: e59038. https://doi.org/10.1371/journal.pone.0059038

Oliveras M., Gómez A. 1989. Corología del género Cystoseira C. Agardh (Phaeophyceae, Fucales). An. Jard. Bot. Madrid 46: 89-97.

Portillo-Hahnefeld E. 2008. Arribazones de algas y plantas marinas en Gran Canaria. Características, gestión y posibles usos. Instituto Tecnológico de Canarias, 86 pp.

Ramírez R., Tuya F., Haroun R.J. 2008. El Intermareal Canario. Poblaciones de lapas, burgados y cañadillas. BIOGES, Universidad de Las Palmas de Gran Canaria, 52 pp.

Riera R., Sangil C., Sansón M. 2015. Long-term herbarium data reveal the decline of a temperate-water algae at its southern range. Est. Coast. Shelf Sci. 165: 159-165. https://doi.org/10.1016/j.ecss.2015.05.008

Rodríguez M., Pérez Ó., Ramos E., et al. 2008. Estudio de la distribución y tamaño de población de la especie Cystoseira abiesmarina (S.G. Gmelin) C. Agardh, 1820 en Canarias. C.I.M.A. Informe Técnico 29, $188 \mathrm{pp}$.

Roskov Y., Abucay L., Orrell T., et al. 2016. Species 2000 \& ITIS Catalogue of Life, 2016 Annual Checklist. Naturalis, Leiden, the Netherlands. http://www.catalogueoflife.org/annual-checklist/2016

Sales M., Cebrian E., Tomas F., et al. 2011. Pollution impacts and recovery potential in three species of the genus Cystoseira $(\mathrm{Fu}-$ cales, Heterokontophyta). Est. Coast. Shelf Sci. 92: 347-357. https://doi.org/10.1016/j.ecss.2011.01.008

Sangil C., Sansón M., Clemente S., et al. 2014. Contrasting the species abundance, species density and diversity of seaweed assemblages in alternative states: Urchin density as a driver of biotic homogenization. J. Sea Res. 85: 92-103. https://doi.org/10.1016/j.seares.2013.10.009

Sansón M. Reyes J., Afonso-Carrillo J. 2001. Flora marina. In: Fernández Palacios J.M., Martín-Esquivel J.L. (eds). Naturaleza de las Islas Canarias: ecología y conservación. Ed. Turquesa. Santa Cruz de Tenerife. pp. 193-198.

Sansón M., Sangil C., Orellana S., et al. 2013. Do the size shifts of marine macroalgae match the warming trends in the Canary Islands? In: XIX Simposio de Botanica Criptogamica. Las Palmas de Gran Canaria, 24-28 June.

Schiel D.R., Foster M.S. 2006. The population biology of large brown seaweeds: ecological consequences of multiphase life histories in dynamic coastal environments. Ann. Rev. Ecol. Evol. Syst. 37: 343-372. https://doi.org/10.1146/annurev.ecolsys.37.091305.110251

Susini M.L., Thibaut T., Meinesz A., et al. 2007. A preliminary study of genetic diversity in Cystoseira amentacea (C. Agardh) Bory var. stricta Montagne (Fucales, Phaeophyceae) using random amplified polymorphic DNA. Phycologia 46: 605-611. https://doi.org/10.2216/06-100.1

Thibaut T., Pinedo S., Torras X., et al. 2005. Long-term decline of the populations of Fucales (Cystoseira spp. and Sargassum spp.) in the Albères coast (France, northwestern Mediterranean). Mar. Poll. Bull. 50: 1472-1489. https://doi.org/10.1016/j.marpolbul.2005.06.014

Thibaut T., Blanfuné A., Markovic L., et al. 2014. Unexpected abundance and long-term relative stability of the brown alga Cystoseira amentacea, hitherto regarded as a threatened species, in the north-western Mediterranean Sea. Mar. Poll. Bull. 89: 305-323. https://doi.org/10.1016/j.marpolbul.2014.09.043

Thibaut T., Blanfuné A., Boudouresque C.F., et al. 2015. Decline and local extinction of Fucales in the French Riviera: the harbinger of future extinctions? Medit. Mar. Sci. 16: 206-224. https://doi.org/10.12681/mms.1032

Thibaut T., Blanfuné A., Verlaque M., et al. 2016a. The Sargassum conundrum: highly rare, threatened or locally extinct in the NW Mediterranean and still lacking protection. Hydrobiologia 781: $3-23$. https://doi.org/10.1007/s10750-015-2580-y

Thibaut T., Blanfuné A., Boudouresque C.F., et al. 2016b. Unexpected temporal stability of Cystoseira and Sargassum forests in Port-Cros, one of the oldest Mediterranean marine National Parks. Cryptogamie Algol. 37: 61-90. https://doi.org/10.7872/crya/v37.iss 1.2016.61

Tuya F., Haroun R. 2006. Spatial patterns and response to wave exposure of photophilic algal assemblages across the Canarian Archipelago: a multi-scaled approach. Mar. Ecol. Prog. Ser. 311: $15-28$ https://doi.org/10.3354/meps311015

Tuya F., Martín J.A., Reuss G.M., et al. 2001. Food preference of the sea urchin Diadema antillarum in Gran Canaria (Canary Island, central-east Atlantic Ocean). J. Mar. Biol. Assoc. U.K. 81: $1-5$. https://doi.org/10.1017/S0025315401004672

Tuya F., Boyra A., Sánchez-Jerez P., et al. 2004. Relationships between rocky-reef fish assemblages, the sea urchin Diadema antillarum and macroalgae throughout the Canarian Archipelago. Mar. Ecol. Prog. Ser. 278: 157-169 https://doi.org/10.3354/meps 278157

Tuya F., Ramírez R., Sánchez-Jerez P., et al. 2006. Coastal resources exploitation can mask bottom-up mesoscale regulation of intertidal populations. Hydrobiologia 553: 337-344. https://doi.org/10.1007/s10750-005-1246-6

Tuya F., Ribeiro-Leite L., Arto-Cuesta N., et al. 2014. Decadal changes in the structure of Cymodocea nodosa seagrass meadows: Natural vs. human influences. Est. Coast. Shelf Sci. 137: 41-49. https://doi.org/10.1016/j.ecss.2013.11.026

Verges A., Alcoverro T., Ballesteros E. 2009. Role of fish herbivory in structuring the vertical distribution of canopy algae Cystoseira spp. in the Mediterranean Sea. Mar. Ecol. Prog. Ser. 375: $1-11$. https://doi.org/10.3354/meps07778

Wahl M., Molis M., Hobday A.J., et al. 2015. The responses of brown macroalgae to environmental change from local to global scales: direct versus ecologically mediated effects. Perspect. Phycol. 2: 11-30. 
https://doi.org/10.1127/pip/2015/0019

Wernberg T., Russell B.D., Thompson M.S., et al. 2011. Seaweed communities in retreat from ocean warming. Curr. Biol. 21: 1-5. https://doi.org/10.1016/j.cub.2011.09.028

Wildpret W., Gil-Rodríguez M.C., Afonso-Carrillo J. 1987. Cartografía de los campos de algas y praderas de fanerógamas marinas del piso infralitoral del Archipiélago Canario. Departamento de Botánica, Facultad de Biología, Universidad de La Laguna. Tomos I, II y III.

Zhang Q.S., Li W., Liu S., et al. 2009. Size-dependence of reproductive allocation of Sargassum thunbergii (Sargassaceae, Phaeophyta) in Bohai Bay, China. Aquat. Bot. 91: 194-198. https://doi.org/10.1016/j.aquabot.2009.06.003

\section{SUPPLEMENTARY MATERIAL}

The following supplementary material is available through the online version of this article and at the following link: http://scimar.icm.csic.es/scimar/supplm/sm04655esm.pdf

Fig. S1. - Cystoseira abies-marina communities in the 1980s, including those from Wildpret et al. (1987) (A) and from oral scientific communications (B).

Table S1. - Cystoseira abies-marina: historical sources (1980s).

Table S2. - Types of human pressures, Corine Land Cover (CLC) codes, area and length percentages, and corresponding scores used in calculations of the HAPI index in coastal sectors and populations of Gran Canaria Island.

Table S3 - Percentages of the area and length of each sector according to human pressure. Pressure scores (PS) assigned to each pressure are indicated. Correlation coefficients $\left(\mathrm{R}^{2}\right)$ between pressures, turnover score (TS) and the HAPI index $(\mathrm{HAPI}=\Sigma(\mathrm{PSi} \times \mathrm{ri}) / \mathrm{TSj})$ were calculated according to Blanfuné et al. 2017 . 


\section{Massive decline of Cystoseira abies-marina forests in Gran Canaria Island (Canary Islands, eastern Atlantic)}

José Valdazo, M. Ascensión Rodríguez-Rodríguez, Fernando Espino, Ricardo Haroun, Fernando Tuya

Supplementary material 

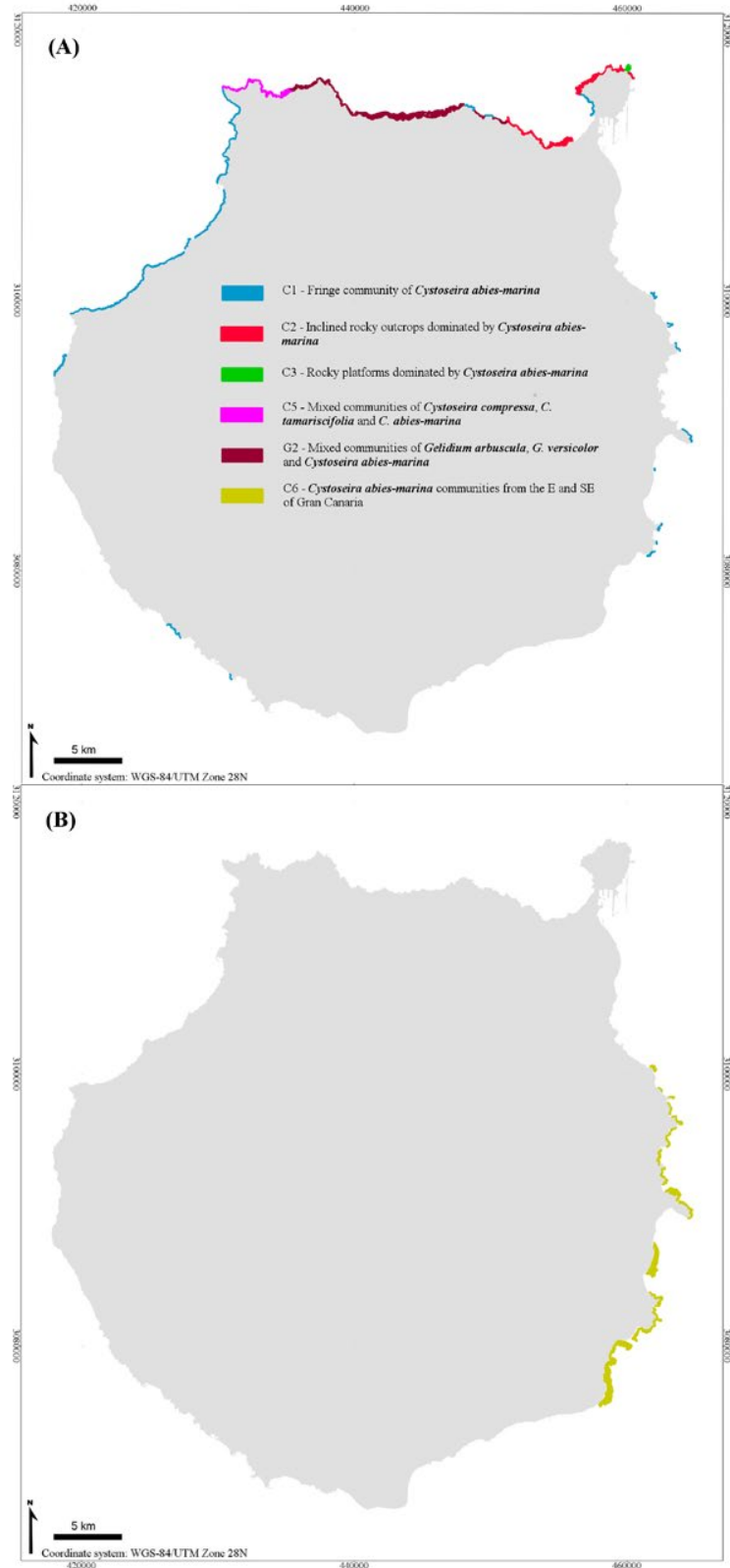

Fig. S1. - Cystoseira abies-marina communities in the 1980s, including those from Wildpret et al. (1987) (A) and from oral scientific communications (B).
Table S2. - Types of human pressures, Corine Land Cover (CLC) codes, area and length percentages, and corresponding scores used in calculations of the HAPI index in coastal sectors and populations of Gran Canaria Island.

\begin{tabular}{lccc}
\hline Types of pressure & CLC code & Area percentage (\%) & Score \\
\hline Continental pressures & & $0-10$ & 1 \\
& & $11-35$ & 2 \\
Urban area & \multirow{2}{*}{1,14} & $36-75$ & 3 \\
& & $>75$ & 4 \\
& & $0-10$ & 1 \\
Industrial area & \multirow{2}{*}{12,13} & $11-25$ & 2 \\
& & $26-75$ & 3 \\
& & $>75$ & 4 \\
Agricultural area & $21-24$ & $0-5$ & 01 \\
& & $6-25$ & 12 \\
Marine pressures & & $16-30$ & 23 \\
& & $>30$ & 34 \\
Coastal artificial- & & Length percentage $(\%)$ & \\
ization & $0-5$ & 1 \\
& & $6-25$ & 2 \\
Sewage outfall & $26-75$ & 3 \\
& & $>75$ & 4 \\
& & $0-5$ & 1 \\
Offshore fish farm & & -25 & 2 \\
& & $26-75$ & 3 \\
& & $>75$ & 4 \\
& & $0-1$ & 1 \\
& & $2-15$ & 2 \\
& & $16-40$ & 3 \\
& & $>40$ & 4 \\
\hline
\end{tabular}

Table S1. - Cystoseira abies-marina: historical sources (1980s).

\begin{tabular}{|c|c|c|c|c|c|c|}
\hline Name & Type & Substrate & Slope & Depth & Cover/Abundant & Source \\
\hline Fringe community of Cystoseira abies-marina & $\mathrm{C} 1$ & Rocky & $80-100 \%$ & $0-3 \mathrm{~m}$ & Continuous belt & Wildpret et al. 1987 \\
\hline $\begin{array}{l}\text { Sloping rocky outcrops dominated by Cystosei- } \\
\text { ra abies-marina }\end{array}$ & $\mathrm{C} 2$ & Rocky & $50-80 \%$ & $0-9 \mathrm{~m}$ & Continuous belt & Wildpret et al. 1987 \\
\hline $\begin{array}{l}\text { Rocky platforms dominated by Cystoseira } \\
\text { abies-marina }\end{array}$ & $\mathrm{C} 3$ & Rocky & $0-50 \%$ & $3-9 \mathrm{~m}$ & Continuous belt & Wildpret et al. 1987 \\
\hline Rocky platform mixed communities & $\mathrm{C} 4$ & Rocky & $0-50 \%$ & $3-9 \mathrm{~m}$ & Continuous belt & Wildpret et al. 1987 \\
\hline $\begin{array}{l}\text { Mixed communities of Cystoseira compressa, } \\
\text { C. tamariscifolia and C. abies-marina }\end{array}$ & $\mathrm{C} 5$ & Rocky & $0-100 \%$ & $\begin{array}{l}0-9 \mathrm{~m} \\
3-9 \mathrm{~m}\end{array}$ & Continuous belt & Wildpret et al. 1987 \\
\hline $\begin{array}{l}\text { Mixed communities of Gelidium arbuscula, } G \text {. } \\
\text { versicolor and Cystoseira abies-marina }\end{array}$ & $\mathrm{G} 2$ & Rocky & $70-100 \%$ & $\begin{array}{l}0-9 \mathrm{~m} \\
3-9 \mathrm{~m}\end{array}$ & Continuous belt & Wildpret et al. 1987 \\
\hline $\begin{array}{l}\text { Cystoseira abies-marina communities from the } \\
\mathrm{E} \text { and SE of Gran Canaria }\end{array}$ & C6 & Rocky & $0-50 \%$ & $0-20 \mathrm{~m}$ & Continuous belt & $\begin{array}{l}\text { Oral scientific } \\
\text { communications }\end{array}$ \\
\hline
\end{tabular}


Table S3. - Percentages of the area and length of each sector according to human pressure. Pressure scores (PS) assigned to each pressure are indicated. Correlation coefficients $\left(\mathrm{R}^{2}\right)$ between pressures, turnover score $(\mathrm{TS})$ and the HAPI index $(\mathrm{HAPIj}=\Sigma(\mathrm{PSi} \times \mathrm{ri}) / \mathrm{TSj})$ were calculated

\begin{tabular}{|c|c|c|c|c|c|c|c|}
\hline Sector & Pressure & $\%$ Area & $\%$ Length & PS & $\mathrm{R}^{2}$ & $\mathrm{TS}$ & HAPI \\
\hline \multirow[t]{6}{*}{1} & Urban area & 9.35 & & 1 & 0.14 & 1.33 & 3.24 \\
\hline & Industrial area & 27.91 & & 3 & 0.31 & & \\
\hline & Agricultural area & 0 & & 0 & 0.06 & & \\
\hline & Coastal artificialization & & 44.74 & 3 & 0.68 & & \\
\hline & Sewage outfall & & 43.46 & 3 & 0.4 & & \\
\hline & Fish farm & & 0 & 0 & 0.15 & & \\
\hline \multirow[t]{6}{*}{2} & Urban area & 72.15 & & 3 & 0.14 & 1 & 5.48 \\
\hline & Industrial area & 21.01 & & 2 & 0.31 & & \\
\hline & Agricultural area & 0.04 & & 2 & 0.06 & & \\
\hline & Coastal artificialization & & 86.66 & 4 & 0.68 & & \\
\hline & Sewage outfall & & 83.03 & 4 & 0.4 & & \\
\hline & Fish farm & & 0 & 0 & 0.15 & & \\
\hline \multirow[t]{6}{*}{3} & Urban area & 28.02 & & 3 & 0.14 & 1 & 4.09 \\
\hline & Industrial area & 24.93 & & 1 & 0.31 & & \\
\hline & Agricultural area & 6.77 & & 2 & 0.06 & & \\
\hline & Coastal artificialization & & 19.07 & 3 & 0.68 & & \\
\hline & Sewage outfall & & 49.29 & 3 & 0.4 & & \\
\hline & Fish farm & & 0 & 0 & 0.15 & & \\
\hline \multirow[t]{6}{*}{4} & Urban area & 25.03 & & 2 & 0.14 & 1 & 3.58 \\
\hline & Industrial area & 18.75 & & 2 & 0.31 & & \\
\hline & Agricultural area & 34.54 & & 2 & 0.06 & & \\
\hline & Coastal artificialization & & 21.46 & 2 & 0.68 & & \\
\hline & Sewage outfall & & 67.63 & 3 & 0.4 & & \\
\hline & Fish farm & & 3.77 & 0 & 0.15 & & \\
\hline \multirow[t]{6}{*}{5} & Urban area & 25.03 & & 2 & 0.14 & 1 & 4 \\
\hline & Industrial area & 18.75 & & 2 & 0.31 & & \\
\hline & Agricultural area & 34.54 & & 4 & 0.06 & & \\
\hline & Coastal artificialization & & 21.46 & 2 & 0.68 & & \\
\hline & Sewage outfall & & 67.63 & 3 & 0.4 & & \\
\hline & Fish farm & & 6.77 & 2 & 0.15 & & \\
\hline \multirow[t]{6}{*}{6} & Urban area & 2.1 & & 1 & 0.14 & 1 & 2.81 \\
\hline & Industrial area & 28.07 & & 3 & 0.31 & & \\
\hline & Agricultural area & 41.16 & & 4 & 0.06 & & \\
\hline & Coastal artificialization & & 0 & 0 & 0.68 & & \\
\hline & Sewage outfall & & 34.56 & 3 & 0.4 & & \\
\hline & Fish farm & & 7.09 & 2 & 0.15 & & \\
\hline \multirow[t]{6}{*}{7} & Urban area & 10.31 & & 2 & 0.14 & 1 & 0.83 \\
\hline & Industrial area & 7.59 & & 1 & 0.31 & & \\
\hline & Agricultural area & 40.97 & & 4 & 0.06 & & \\
\hline & Coastal artificialization & & 0 & 0 & 0.68 & & \\
\hline & Sewage outfall & & 0 & 0 & 0.4 & & \\
\hline & Fish farm & & 0 & 0 & 0.15 & & \\
\hline \multirow[t]{6}{*}{8} & Urban area & 6.71 & & 1 & 0.14 & 1 & 4.55 \\
\hline & Industrial area & 32.66 & & 3 & 0.31 & & \\
\hline & Agricultural area & 31.55 & & 4 & 0.06 & & \\
\hline & Coastal artificialization & & 36.18 & 3 & 0.68 & & \\
\hline & Sewage outfall & & 47.73 & 3 & 0.4 & & \\
\hline & Fish farm & & 0 & 0 & 0.15 & & \\
\hline \multirow[t]{6}{*}{9} & Urban area & 4.4 & & 1 & 0.14 & 1 & 4.85 \\
\hline & Industrial area & 28.19 & & 3 & 0.31 & & \\
\hline & Agricultural area & 50.86 & & 4 & 0.06 & & \\
\hline & Coastal artificialization & & 34.83 & 3 & 0.68 & & \\
\hline & Sewage outfall & & 32.88 & 3 & 0.4 & & \\
\hline & Fish farm & & 13.57 & 2 & 0.15 & & \\
\hline 10 & Urban area & 2.02 & & 1 & 0.14 & 1 & 3.13 \\
\hline & Industrial area & 9.11 & & 1 & 0.31 & & \\
\hline & Agricultural area & 12.61 & & 2 & 0.06 & & \\
\hline & Coastal artificialization & & 20.79 & 2 & 0.68 & & \\
\hline & Sewage outfall & & 48.75 & 3 & 0.4 & & \\
\hline & Fish farm & & 0 & 0 & 0.15 & & \\
\hline 11 & Urban area & 11.13 & & 2 & 0.14 & 0.8 & 4.09 \\
\hline & Industrial area & 0.84 & & 1 & 0.31 & & \\
\hline & Agricultural area & 6.78 & & 2 & 0.06 & & \\
\hline & Coastal artificialization & & 20.171 & 2 & 0.68 & & \\
\hline & Sewage outfall & & 68.83 & 3 & 0.4 & & \\
\hline & Fish farm & & 0 & 0 & 0.15 & & \\
\hline 12 & Urban area & 59.95 & & 3 & 0.14 & 0.8 & 4.19 \\
\hline & Industrial area & 4.9 & & 1 & 0.31 & & \\
\hline & Agricultural area & 0.93 & & 1 & 0.06 & & \\
\hline & Coastal artificialization & & 12.06 & 2 & 0.68 & & \\
\hline & Sewage outfall & & 29.12 & 3 & 0.4 & & \\
\hline & Fish farm & & 0 & 0 & 0.15 & & \\
\hline
\end{tabular}


Table S3 (Cont.). - Percentages of the area and length of each sector according to human pressure. Pressure scores (PS) assigned to each pressure are indicated. Correlation coefficients $\left(\mathrm{R}^{2}\right)$ between pressures, turnover score $(\mathrm{TS})$ and the HAPI index $(\mathrm{HAPIj}=\Sigma(\mathrm{PSi} \times \mathrm{ri}) / \mathrm{TS} \mathrm{j}) \mathrm{were}$ calculated according to Blanfuné et al. 2017.

\begin{tabular}{|c|c|c|c|c|c|c|c|}
\hline Sector & Pressure & $\%$ Area & $\%$ Length & PS & $\mathrm{R}^{2}$ & TS & HAPI \\
\hline \multirow[t]{6}{*}{13} & Urban area & 8.28 & & 1 & 0.14 & 0.8 & 3.83 \\
\hline & Industrial area & 0.75 & & 1 & 0.31 & & \\
\hline & Agricultural area & 58.21 & & 3 & 0.06 & & \\
\hline & Coastal artificialization & & 32.74 & 3 & 0.68 & & \\
\hline & Sewage outfall & & 5.87 & 1 & 0.4 & & \\
\hline & Fish farm & & 0 & 0 & 0.15 & & \\
\hline \multirow[t]{6}{*}{14} & Urban area & 17.86 & & 2 & 0.14 & 0.8 & 4.09 \\
\hline & Industrial area & 7.29 & & 1 & 0.31 & & \\
\hline & Agricultural area & 10.72 & & 2 & 0.06 & & \\
\hline & Coastal artificialization & & 14.05 & 2 & 0.68 & & \\
\hline & Sewage outfall & & 71.96 & 3 & 0.4 & & \\
\hline & Fish farm & & 0 & 0 & 0.15 & & \\
\hline \multirow[t]{6}{*}{15} & Urban area & 12.97 & & 2 & 0.14 & 0.8 & 4.44 \\
\hline & Industrial area & 0.6 & & 1 & 0.31 & & \\
\hline & Agricultural area & 0 & & 0 & 0.06 & & \\
\hline & Coastal artificialization & & 23 & 2 & 0.68 & & \\
\hline & Sewage outfall & & 75.59 & 4 & 0.4 & & \\
\hline & Fish farm & & 0 & 0 & 0.15 & & \\
\hline \multirow[t]{6}{*}{16} & Urban area & 1.72 & & 1 & 0.14 & 0.8 & 4.37 \\
\hline & Industrial area & 0 & & 0 & 0.31 & & \\
\hline & Agricultural area & 11.71 & & 2 & 0.06 & & \\
\hline & Coastal artificialization & & 29.74 & 3 & 0.68 & & \\
\hline & Sewage outfall & & 33.16 & 3 & 0.4 & & \\
\hline & Fish farm & & 0 & 0 & 0.15 & & \\
\hline \multirow[t]{6}{*}{17} & Urban area & 0 & & 0 & 0.14 & 0.8 & 0.075 \\
\hline & Industrial area & 0 & & 0 & 0.31 & & \\
\hline & Agricultural area & 5.67 & & 1 & 0.06 & & \\
\hline & Coastal artificialization & & 0 & 0 & 0.68 & & \\
\hline & Sewage outfall & & 0 & 0 & 0.4 & & \\
\hline & Fish farm & & 0 & 0 & 0.15 & & \\
\hline \multirow[t]{6}{*}{18} & Urban area & 0 & & 0 & 0.14 & 1 & 0.06 \\
\hline & Industrial area & 0 & & 0 & 0.31 & & \\
\hline & Agricultural area & 4.3 & & 1 & 0.06 & & \\
\hline & Coastal artificialization & & 0 & 0 & 0.68 & & \\
\hline & Sewage outfall & & 0 & 0 & 0.4 & & \\
\hline & Fish farm & & 0 & 0 & 0.15 & & \\
\hline \multirow[t]{6}{*}{19} & Urban area & 0 & & 0 & 0.14 & 1 & 0.06 \\
\hline & Industrial area & 0 & & 0 & 0.31 & & \\
\hline & Agricultural area & 4.37 & & 1 & 0.06 & & \\
\hline & Coastal artificialization & & 0 & 0 & 0.68 & & \\
\hline & Sewage outfall & & 0 & 0 & 0.4 & & \\
\hline & Fish farm & & 0 & 0 & 0.15 & & \\
\hline \multirow[t]{6}{*}{20} & Urban area & 2.34 & & 1 & 0.14 & & 1.8 \\
\hline & Industrial area & 0 & & 0 & 0.31 & & \\
\hline & Agricultural area & 22.39 & & 3 & 0.06 & 1 & \\
\hline & Coastal artificialization & & 3.56 & 1 & 0.68 & & \\
\hline & Sewage outfall & & 11.13 & 2 & 0.4 & & \\
\hline & Fish farm & & 0 & 0 & 0.15 & & \\
\hline \multirow[t]{6}{*}{21} & Urban area & 0 & & 0 & 0.14 & 1.33 & 0.045 \\
\hline & Industrial area & 0 & & 0 & 0.31 & & \\
\hline & Agricultural area & 1.17 & & 1 & 0.06 & & \\
\hline & Coastal artificialization & & 0 & 0 & 0.68 & & \\
\hline & Sewage outfall & & 0 & 0 & 0.4 & & \\
\hline & Fish farm & & 0 & 0 & 0.15 & & \\
\hline 22 & Urban area & 0 & & 0 & 0.14 & 1.33 & 0.044 \\
\hline & Industrial area & 0 & & 0 & 0.31 & & \\
\hline & Agricultural area & 2.07 & & 1 & 0.06 & & \\
\hline & Coastal artificialization & & 0 & 0 & 0.68 & & \\
\hline & Sewage outfall & & 0 & 0 & 0.4 & & \\
\hline & Fish farm & & 0 & 0 & 0.15 & & \\
\hline 23 & Urban area & 7.1 & & 1 & 0.14 & 1.33 & 2.44 \\
\hline & Industrial area & 3.16 & & 1 & 0.31 & & \\
\hline & Agricultural area & 47.59 & & 4 & 0.06 & & \\
\hline & Coastal artificialization & & 0 & 2 & 0.68 & & \\
\hline & Sewage outfall & & 0 & 3 & 0.4 & & \\
\hline & Fish farm & & 0 & 0 & 0.15 & & \\
\hline 24 & Urban area & 10.44 & & 1 & 0.14 & 1.33 & 1.93 \\
\hline & Industrial area & 10.71 & & 1 & 0.31 & & \\
\hline & Agricultural area & 41.45 & & 4 & 0.06 & & \\
\hline & Coastal artificialization & & 4.15 & 1 & 0.68 & & \\
\hline & Sewage outfall & & 41.74 & 3 & 0.4 & & \\
\hline & Fish farm & & 0 & 0 & 0.15 & & \\
\hline
\end{tabular}


Table S3 (Cont.). - Percentages of the area and length of each sector according to human pressure. Pressure scores (PS) assigned to each pressure are indicated. Correlation coefficients $\left(\mathrm{R}^{2}\right)$ between pressures, turnover score $(\mathrm{TS})$ and the HAPI index $(\mathrm{HAPIj}=\Sigma(\mathrm{PSi} \times \mathrm{ri}) / \mathrm{TSj})$ were calculated according to Blanfuné et al. 2017.

\begin{tabular}{|c|c|c|c|c|c|c|c|}
\hline Sector & Pressure & $\%$ Area & $\%$ Length & PS & $\mathrm{R}^{2}$ & TS & HAPI \\
\hline \multirow[t]{6}{*}{25} & Urban area & 14.98 & & 2 & 0.14 & 1.33 & 1.53 \\
\hline & Industrial area & 0.84 & & 1 & 0.31 & & \\
\hline & Agricultural area & 59.7 & & 4 & 0.06 & & \\
\hline & Coastal artificialization & & 0 & 0 & 0.68 & & \\
\hline & Sewage outfall & & 45.91 & 3 & 0.4 & & \\
\hline & Fish farm & & 0 & 0 & 0.15 & & \\
\hline \multirow[t]{6}{*}{26} & Urban area & 5.33 & & 1 & 0.14 & 1.33 & 1.42 \\
\hline & Industrial area & 1.22 & & 1 & 0.31 & & \\
\hline & Agricultural area & 39.31 & & 4 & 0.06 & & \\
\hline & Coastal artificialization & & 0 & 0 & 0.68 & & \\
\hline & Sewage outfall & & 62.18 & 3 & 0.4 & & \\
\hline & Fish farm & & 0 & 0 & 0.15 & & \\
\hline \multirow[t]{6}{*}{27} & Urban area & 14.55 & & 2 & 0.14 & 1.33 & 2.55 \\
\hline & Industrial area & 0.48 & & 1 & 0.31 & & \\
\hline & Agricultural area & 45.37 & & 4 & 0.06 & & \\
\hline & Coastal artificialization & & 9.99 & 2 & 0.68 & & \\
\hline & Sewage outfall & & 67.61 & 3 & 0.4 & & \\
\hline & Fish farm & & 0 & 0 & 0.15 & & \\
\hline \multirow[t]{6}{*}{28} & Urban area & 13.44 & & 2 & 0.14 & 1.33 & 1.52 \\
\hline & Industrial area & 5.98 & & 1 & 0.31 & & \\
\hline & Agricultural area & 41.59 & & 4 & 0.06 & & \\
\hline & Coastal artificialization & & 0 & 0 & 0.68 & & \\
\hline & Sewage outfall & & 42.19 & 3 & 0.4 & & \\
\hline & Fish farm & & 0 & 0 & 0.15 & & \\
\hline
\end{tabular}

